\title{
A Study of Attitude, Awareness and Practice on Female Feticide of Pregnant Women in Bikaner of Rajasthan
}

\author{
Authors \\ Dr Seema Mehta ${ }^{1}$, Aarti acharya ${ }^{2}$, Dr Rattiram Meena ${ }^{3 *}$, Dr Rekha Acharya ${ }^{4}$, \\ Dr Gaurav Sharma ${ }^{5}$ \\ ${ }^{1}$ Senior Demonstrator, ${ }^{2}$ Intern, ${ }^{3}$ Resident Doctor, ${ }^{4}$ Professor and HOD, ${ }^{5}$ Associate Professor \\ 1,3,4,5 Department of Preventive And Social Medicine, Sardar Patel Medical College, Bikaner. \\ Correspondence Author \\ Dr Rattiram Meena \\ Department of Preventive and Social Medicine, Sardar Patel Medical College, Bikaner INDIA
}

\begin{abstract}
Background: Skewed sex ratio is an issue of major concern and has long-term social and demographic consequences.

Methods: A cross-sectional study was conducted in ANC center of Medical college Hospital, Bikaner of Rajasthan in 400 pregnant women. A pre-tested and pre-structured questionnaire was used to collect information on their knowledge and attitudes towards gender preference and female feticide.

Results: Out of 400 pregnant women selected for interview, 55\% were unaware of the legal age of marriage but $77.5 \%$ knew that pre-natal sex determination can be done and $81 \%$ were also knowing USG technique used for sex determination. However $67.5 \%$ were unaware about PNDT Act.

Conclusions: It is necessary to gear the efforts against this social malady by intensive IEC campaigns for raising awareness about rules forbidding pre-natal sex determination and strict implementation of PNDT Act.

Keywords: Female feticide, Attitude, Awareness, Practice, Pregnant women.
\end{abstract}

\section{INTRODUCTION}

Declining sex ratio is an issue of grave concern in India. A preference for boys cuts across caste and class lines and results in discrimination against girls even before they are born. The United Nations Children's fund states that systematic gender discrimination has resulted in upto 50 million girls and women "going missing from India's population" ${ }^{\text {. These findings are supported }}$ by abnormal sex figures found in Census $2001^{2}$.

Killing girl child in the womb of mother is known as female feticide and is very common in Asian countries like India. Everyday there is news in the newspaper or on the TV that a new born girl is found in dustbin or garbage. The ratio of women is increasing for 1000 men there are only 940 women in India. Although lot of advertising is done by Government, but still the condition is same nothing helps and there are several reasons behind $\mathrm{it}^{3}$.

The male child was important and enhances the status of the family; they preferred the first offspring as male. Also the girl child was seen as a liability and was not desired as the first child. The 


\section{JMSCR Vol||05||Issue||01||Pages 17185-17187||January}

value of male child in a patriarchal society ensures differential treatment of the girl child in comparison with the male child. Practices reflective of the high worth of the male child have existed traditionally from birth itself where a girl child may be decisively denied the right to life or her life chances may be reduced through cultural neglect where basic maternal care, nutrition or medical care may not be denied to her. ${ }^{4}$

\section{METHODS}

Study Design: Hospital based cross-sectional study

Study Place: Dept. of gyane\& Obst. (ANC Center), S.P.Medical College and P.B.M Hospital, Bikaner

Study Population: Women who come for ANC examination .

Sampling Method: purposive sample technique.

Data Collection: Data collection was done by a Doctor. A predesigned pre-tested proforma was used to elicit information on the knowledge of sex determination techniques and perceptions regarding gender discrimination from married women in rural areas. Verbal consent was taken before filling the questionnaire.

\section{RESULTS}

Table 1: Distribution of patient according to frequency and percentage of demographic variable, $n=400$

\begin{tabular}{|c|c|c|c|}
\hline Sr.No. & Variables & Frequency & Percentage \\
\hline \multirow[t]{4}{*}{1 Age Group } & $18-21$ & 160 & $40 \%$ \\
\hline & $22-25$ & 190 & $47.5 \%$ \\
\hline & $26-29$ & 45 & $11.25 \%$ \\
\hline & $\begin{array}{c}30 \text { And More } \\
\text { Than } 30\end{array}$ & 5 & $1.25 \%$ \\
\hline \multirow[t]{2}{*}{2 Religion } & Hindu & 260 & $65 \%$ \\
\hline & Muslim & 140 & $35 \%$ \\
\hline \multirow[t]{2}{*}{$\begin{array}{l}4 \text { Type Of } \\
\text { Family }\end{array}$} & Joint & 350 & $87.5 \%$ \\
\hline & Nuclear & 50 & $12.5 \%$ \\
\hline
\end{tabular}

The data presented in table no 1 shows that $47.5 \%$ women were in the age group of 22-25 yrs, 65\% women belongs to Hindu religion. Majority $87.5 \%$ belongs to joint family.
Table 2: Awareness of Females regarding issues of Sex determination

\begin{tabular}{|c|c|c|c|}
\hline \multicolumn{2}{|l|}{ Awareness } & \multirow{2}{*}{$\begin{array}{c}\begin{array}{c}\text { No. of } \\
\text { pregnant } \\
\text { females }\end{array} \\
180\end{array}$} & \multirow{2}{*}{$\begin{array}{c}\text { Percentage } \\
45 \%\end{array}$} \\
\hline Legal age of & Aware & & \\
\hline & $\begin{array}{l}\text { Not } \\
\text { aware }\end{array}$ & 220 & $55 \%$ \\
\hline \multirow{2}{*}{$\begin{array}{l}\text { Pre-natal Sex } \\
\text { determination } \\
\text { can be done }\end{array}$} & Aware & 310 & $77.5 \%$ \\
\hline & $\begin{array}{l}\text { Not } \\
\text { aware }\end{array}$ & 90 & $22.5 \%$ \\
\hline \multirow{2}{*}{$\begin{array}{l}\text { USG technique } \\
\text { used for sex } \\
\text { determination }\end{array}$} & Aware & 324 & $81 \%$ \\
\hline & $\begin{array}{l}\text { Not } \\
\text { aware }\end{array}$ & 76 & $19 \%$ \\
\hline \multirow{2}{*}{$\begin{array}{l}\text { Knowledge } \\
\text { regarding PNDT } \\
\text { Act }\end{array}$} & Aware & 130 & $32.5 \%$ \\
\hline & $\begin{array}{l}\text { Not } \\
\text { aware }\end{array}$ & 270 & $67.5 \%$ \\
\hline
\end{tabular}

Out of 400 pregnant women selected for interview, 55\% were unaware of the legal age of marriage but $77.5 \%$ knew that pre-natal sex determination can be done and $81 \%$ were also knowing USG technique used for sex determination. However $67.5 \%$ were unaware about PNDT Act.

Table - 3: Perceptions and Practices of Females regarding Sex related Issues

\begin{tabular}{|c|c|c|c|}
\hline \multicolumn{2}{|c|}{ Perceptions and Practices } & \multirow{2}{*}{$\begin{array}{c}\begin{array}{c}\text { No. of } \\
\text { pregnant } \\
\text { females }\end{array} \\
46\end{array}$} & \multirow{2}{*}{$\begin{array}{c}\text { Percentage } \\
11.5 \% \\
\end{array}$} \\
\hline Females enjoy & Yes & & \\
\hline $\begin{array}{l}\text { equal rights as } \\
\text { males }\end{array}$ & No & 354 & $88.5 \%$ \\
\hline \multirow{2}{*}{$\begin{array}{lr}\text { Prenatal } & \text { Sex } \\
\text { determination } & \text { is } \\
\text { justified } & \end{array}$} & Yes & 116 & $29 \%$ \\
\hline & No & 284 & $61 \%$ \\
\hline \multirow{2}{*}{$\begin{array}{l}\text { Family complete } \\
\text { with girl child, } \\
\text { will try for male }\end{array}$} & Yes & 280 & $70 \%$ \\
\hline & No & 120 & $30 \%$ \\
\hline
\end{tabular}

Regarding perceptions $88.5 \%$ were of view that females still do not enjoy equal rights as males. $29 \%$ were willing to go for pre-natal sex determination and $70 \%$ of females expressed views that they would prefer to go for son even if the family gets completed with females.

\section{DISCUSSION}

Out of 400 pregnant women selected for interview, 55\% were unaware of the legal age of 
marriage but $77.5 \%$ knew that pre-natal sex determination can be done and $81 \%$ were also knowing USG technique used for sex determination. However $67.5 \%$ were unaware about PNDT Act. Similar implications were reported by Vadera et.al ${ }^{5}$ and Ajinder Walia et al. $^{6}$

Regarding perceptions $88.5 \%$ were of view that females still do not enjoy equal rights as males. $29 \%$ were willing to go for pre-natal sex determination and $70 \%$ of females expressed views that they would prefer to go for son even if the family gets completed with females. A study carried out by Puri.et.al ${ }^{7}$ also concluded that $56 \%$ females had preference to male child.

\section{CONCLUSION}

It is necessary to gear the efforts against this social malady by intensive IEC campaigns for raising awareness about rules forbidding pre-natal sex determination and strict implementation of PNDT Act. At the heart of problem is impact of advertisement about the facility of prenatal sex determination and the unawareness of legal regulations forbidding feticide as PNDT Act.

Funding: No funding sources

Conflict of interest: None declared

Ethical Approval: The study was approved by the Institutional Ethics Committee

\section{REFERENCES}

1. Female foeticide in India. C2007. Available from http://www.unicef.org/india/ media 3285.htm. [cited on 2008 Jun 26]

2. Census Figures of 2001. Office of the Registrar General and Census Commissioner, New Delhi, India.

3. Benji Stephan: Girl child-a reality of "existence" Herald of health 2007:27.

4. Grewal I, Kishore J. Female feticide in India. International Humanist News, 2004.

5. Vadera BN, Joshi UK, Unadakat SV, Yadav BS, Yadav S. Study on Knowledge, attitude and practices regarding gender preference and female feticide among pregnant women. Indian $\mathrm{J}$ Community Med 2007;32:300-1

6. Walia A. Female feticide in Punjab: exploring the socio-economic and cultural dimensions. A journal of social issues. 2005;10:1.

7. Puri S, Bhatia V, Swami HM. Gender preference and awareness regarding sex determination among married women in slums of Chandigarh. Indian J Community Med 2007;1:60-2. 